\title{
TITLE:
}

\section{ON SOME COMATULIDS FROM THE COASTAL SEA OF KII PENINSULA}

\author{
$\operatorname{AUTHOR}(\mathrm{S})$ :
}

Utinomi, Huzio; Kogo, Ichizo

\section{CITATION:}

Utinomi, Huzio ...[et al]. ON SOME COMATULIDS FROM THE COASTAL SEA OF KII

PENINSULA. PUBLICATIONS OF THE SETO MARINE BIOLOGICAL LABORATORY 1965, 13(4): 263-286

\section{ISSUE DATE:}

1965-12-15

URL:

http://hdl.handle.net/2433/175412

RIGHT: 


\title{
ON SOME COMATULIDS FROM THE COASTAL SEA OF KII PENINSULA ${ }^{13}$
}

\author{
HuZIo UTINOMI \\ Seto Marine Biological Laboratory, Sirahama \\ and \\ ICHIzO KOGO \\ Umeda-Higashi Primary School, Osaka \\ With Plate XII and 14 Text-figures
}

The present paper deals with the specimens belonging to the order Comatulida A. H. CLARK, which have been assembled from the southwest coast of Kii Peninsula, especially from Tanabe Bay and its adjacent waters during the period from 1922 to 1961 . This study revealed that there are in all 19 species belonging to 17 genera of 8 families of Comatulids in the concerned area. 2 species of them were newly found by the junior author and added to the Japanese fauna. They are Comanthina schlegeli and Lamprometra parmata parmata. These species were collected from a relatively shallow water.

GisLÉN (1927) has already listed a total of 91 species among the Crinoidea including some stalked forms which were collected around southern Japanese waters. He obtained almost all his materials from much deeper waters than we did. In our opinion there could be probably found more species if attempts were made to survey in shallower water.

As to the methods of classification we followed the CLARK's system appeared in his monographs $(1915 \mathrm{~b}-1950)$ in general, but in some particular cases such as the case of subgenus Comanthus, it was needed to use our own system.

The following species are described:

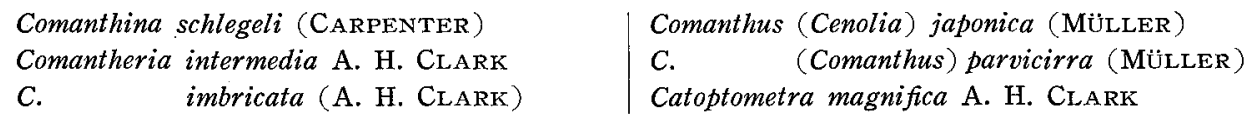

1) Contributions from the Seto Marine Biological Laboratory, No. 442.

Publ, Seto Mar, Biol, Lab., XIII (4), 263-286, 1965. (Article 14) 
Liparometra grandis (A. H. ClARK)

Lamprometra parmata parmata (MÜLLER)

Iconometra japonica (HARTLAUB)

Cyllometra manca (CARPENTER)

Decametra parva (A. H. CLARK)

Tropiometra afra macrodiscus (HARA)

Pectinometra flavopurpurea (A. H. CLARK)
Calometra callista (A. H. CLARK)

Stenometra diadema (A. H. CLARK)

Compsometra serrata (A. H. CLARK)

Eumetra aphrodite (A. H. CLARK)

Perometra diomedeae (A. H. CIARK)

Erythrometra rubra (A. H. CLARK)

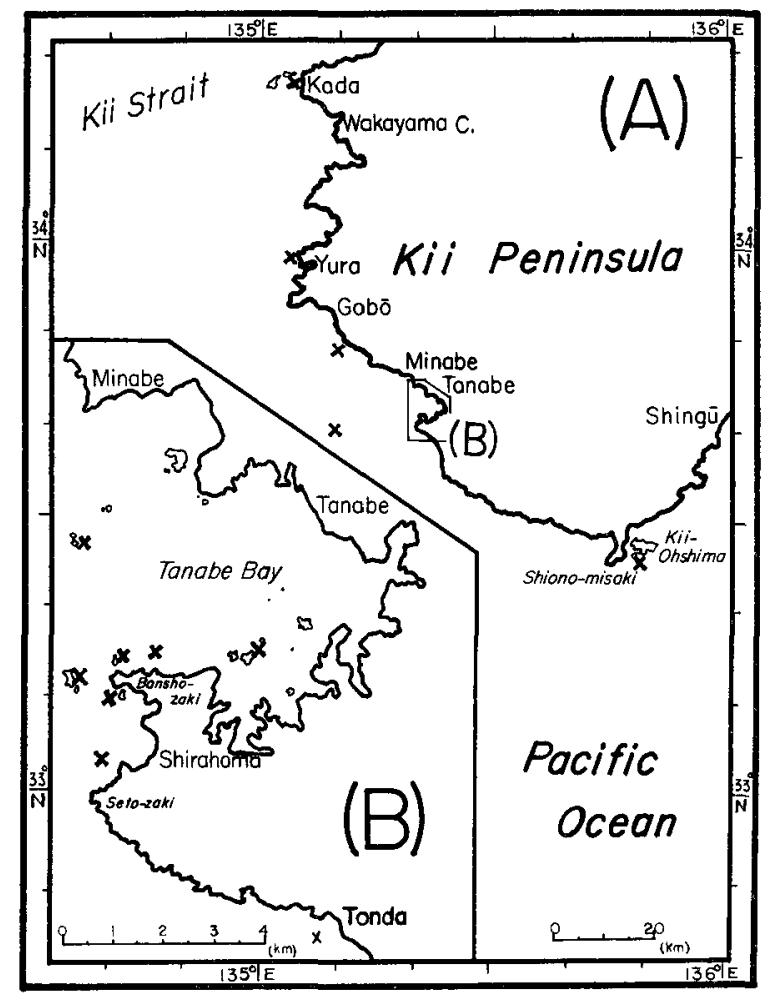

Fig. 1. Chart showing the position of collecting $(x)$.

We are deeply indebted to Mr. Torao Yamamoto, Mr. Chûichi Araga and staff members of the Aquarium of our laboratory for offering us the materials of Comatulids. Our thanks are also due to Mr. Ichiro YAGURA, captain of the trawler "Kaiun-maru" and his crew at Minabe for giving aid in collecting the material. Colour photographs except one for Comanthina schlegeli (CARPENTER) were kindly made by Mr. Chûichi ARAGA to whom we are very grateful.

This study was supported in part by a grant-in-aid from the Scientific Research Fund of the Ministry of Education. 


\author{
Systematics \\ CLASS CRINOIDEA \\ Order Comatulida \\ Suborder Oligophreata A. H. ClARK \\ Superfamily Comasterida GISLÉN \\ Family Comasteridae A. H. Clark \\ Subfamily Comasterinae A. H. CLARK \\ 1. Comanthina schlegeli (CARPENTER)
}

(Plate XII, fig. 1; Text-figs. 2-3)

Actinometra novae-guineae CARPENTER, 1879, p. 386 (after CLARK, 1931)
Comanthus schlegeli H. L. CLARK, 1921, p. 20.
Comanthina schlegeli A. H. CLARK, 1931 , p. 466 .

Japanese name: Hana-umishida (nom. nov.)

Materials examined: 2 specimens; Seto, Shirahama; VIII-1922. 1 specimen; Seto, Shirahama; VIII-1924. 1 specimen; Kii-ohshima; VI-1937. 2 specimens; Kii-ohshima; VII1937. 1 specimen; Locality unrecorded; VI-1939. 2 specimens; Locality unrecorded; 17-VII1939. 1 specimen; Locality unrecorded; VIII-1942. 1 specimen; Tsuyajima near Shiono-misaki ; T. Yамамото coll.; 27-VIII-1959. 1 specimen; Seto, Shirahama; rocky bottom, $5 \mathrm{~m}$ deep; I. KoGo coll.; VII-1961. 1 specimen; Seto, Shirahama ; rocky bottom, $3 \mathrm{~m}$ deep ; I. KoGO coll.; 7-VIII-1961. 1 specimen; Kanô-jima, Tanabe Bay; rocky bottom, $5 \mathrm{~m}$ deep; I. KoGo coll.; 24-VIII-1961. 1 specimen; Kanô-jima, Tanabe Bay; rocky bottom, $3 \mathrm{~m}$ deep; I. Kogo coll.; 8-IX-1961.

Description: (on a medium-sized specimen) The centro-dorsal is thin pentagonal, $47 \mathrm{~mm}$ across with the free dorsal area which is $3.7 \mathrm{~mm}$ across, and is slightly convex without central pit, but in other specimens this area is usually concave. The cirri are exceedingly rudimental, 11 in number, but in one exceptional case there is found a cirrus composed of 15 short segments, non-functional, $4.7 \mathrm{~mm}$ long. Each cirral is entirely smooth on its surface excepting the penultimate segment with a pair of opposing spines. The disk is $25 \mathrm{~mm}$ in diameter. The anal-cone is central, $5 \mathrm{~mm}$ in height. The mouth is somewhat peripheral. The division series are tightly contiguous. The $\mathrm{IBr}$-series are wholly 2 , the IIBr-series all $4(3+4)$, the IIIBr-series generally 2 on the outer side and $4(3+4)$ on the inner. The IVBr-series are mostly $4(3+4)$, but partly 2. Perisomic plates are conspicuous between the division series.

The arms are 108 in number, $60-80 \mathrm{~mm}$ long, and multibrachiated. Syzygies occur between $3+4$, again from $9+10$ to $14+15$, and distally at intervals of $3-5$, usually 4 , musçular articulations, The terminal combs extend to 
beyond $P_{8}$, in other specimens these are exceptionally confined to the lower pinnules. $P_{1}$ is composed of about 45 segments with nearly 10 forked teeth on the distal part, $17 \mathrm{~mm}$ long; $\mathrm{P}_{2} 25$ segments with 7 forked teeth, $7 \mathrm{~mm}$ long; $P_{3} 21$ segments with or without the teeth. $P_{3}$ is the shortest pinnule. These pinnulars are provided with a number of minute spines on the distal margin of the segment.

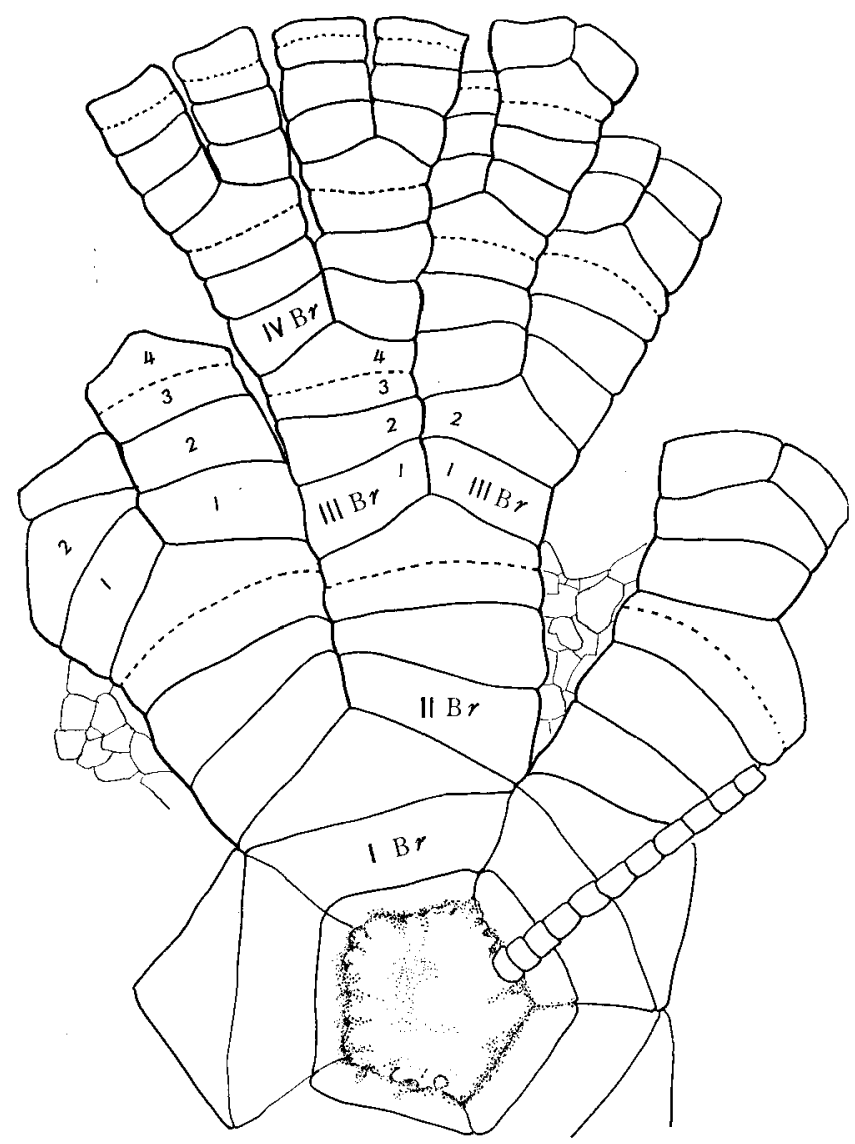

Fig. 2. Comanthina schlegeli (CARPENTER). Division series, $\times 4$.

Colour: This animal seems to be the most colourful Comatulid in this area. When alive, the centro-dorsal, pinnules and proximal half of the arm are white, the perisomic area of arm is yellow, the disk yellowish green, and the ambulacral groove as well as the bilateral sides of pinnule are black. Occasionally there are found bicoloured animals which are entirely jetblack on the soft part of the body and white on the rest. 
Biology: This is a shallow water inhabitant in the vicinity of Shirahama. The animals are frequently picked up by lobster-nets during winter. No record from the depth over 30 meters have been made until the present time.

By the shore, the animal is generally found at rocky bottom where a tidal current flows rapidly. The arms are comparatively slender and weak to the animal, so that they cannot swim at all.

Among many commensals, Harrovia elegans DE MAN and Galathea sp. are usually found. There are, occasionally, found some of Myzostomum sp. with an opening to the ambulacral groove of the disk or arm beneath the epidermis.
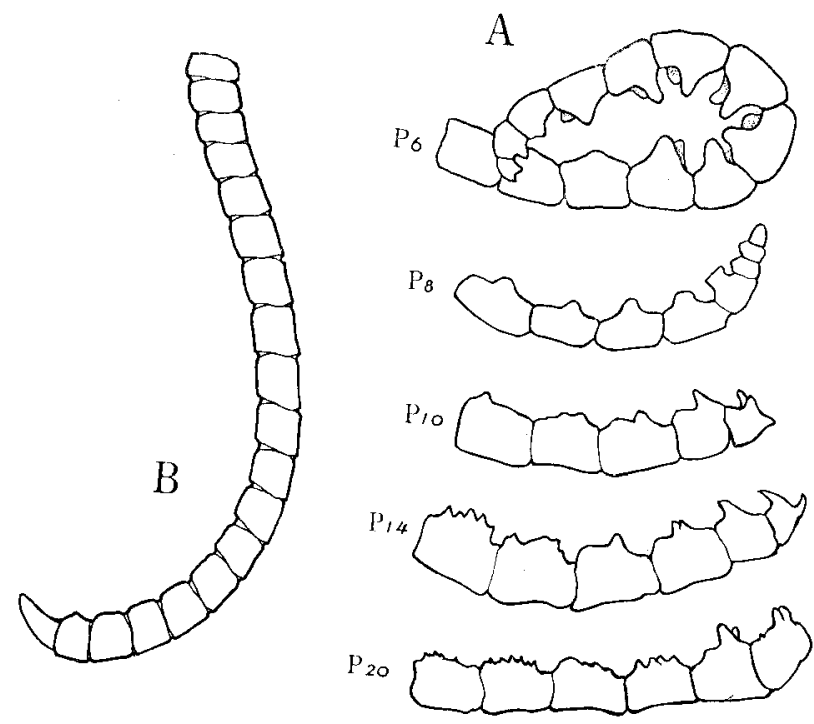

Fig. 3. Comanthina schlegeli (CARPENTER). A, Comb-like structure of some pinnules, $\times 10$. B, One developed cirrus, $\times 5$.

Remarks: CLARK (1931) said that Comanthina schlegeli is readily distinguishable from $C$. belli because of the absence of the high carinate processes on the lower pinnule segments in the latter. However, we had been troubled at this point of view, since these segments seemed to have low carination in our specimens, therefore we could not conclude about this.

Distribution: Maldive Islands and Ceylon, northern Australia, Solomon Islands, Carolines, the Philippines, and Macclesfield Bank. Newly known to Japan. The specimens were hitherto obtained from the shore line down to $278 \mathrm{~m}$, commonly $30 \mathrm{~m}$ in depth. While in this area they tend to distribute in apparently shallow water and never descend to over $30 \mathrm{~m}$ in depth. 


\section{Comantheria intermedia A. H. CLARK}

(Text-fig. 4)

Comantheria intermedia A. H. CLARK, 1915a, p. $214 ;-, 1918$, p. 43 ;-, 1931, p. 508, pl. 60, figs. $169,171,172$, pl. 65 , fig. 182 .

Japanese name: Ashiboso-ohban-umishida.

Material examined: 1 specimen; Tonda, Shirahama ; $50 \mathrm{~m}$ deep ; 14-III-1937.

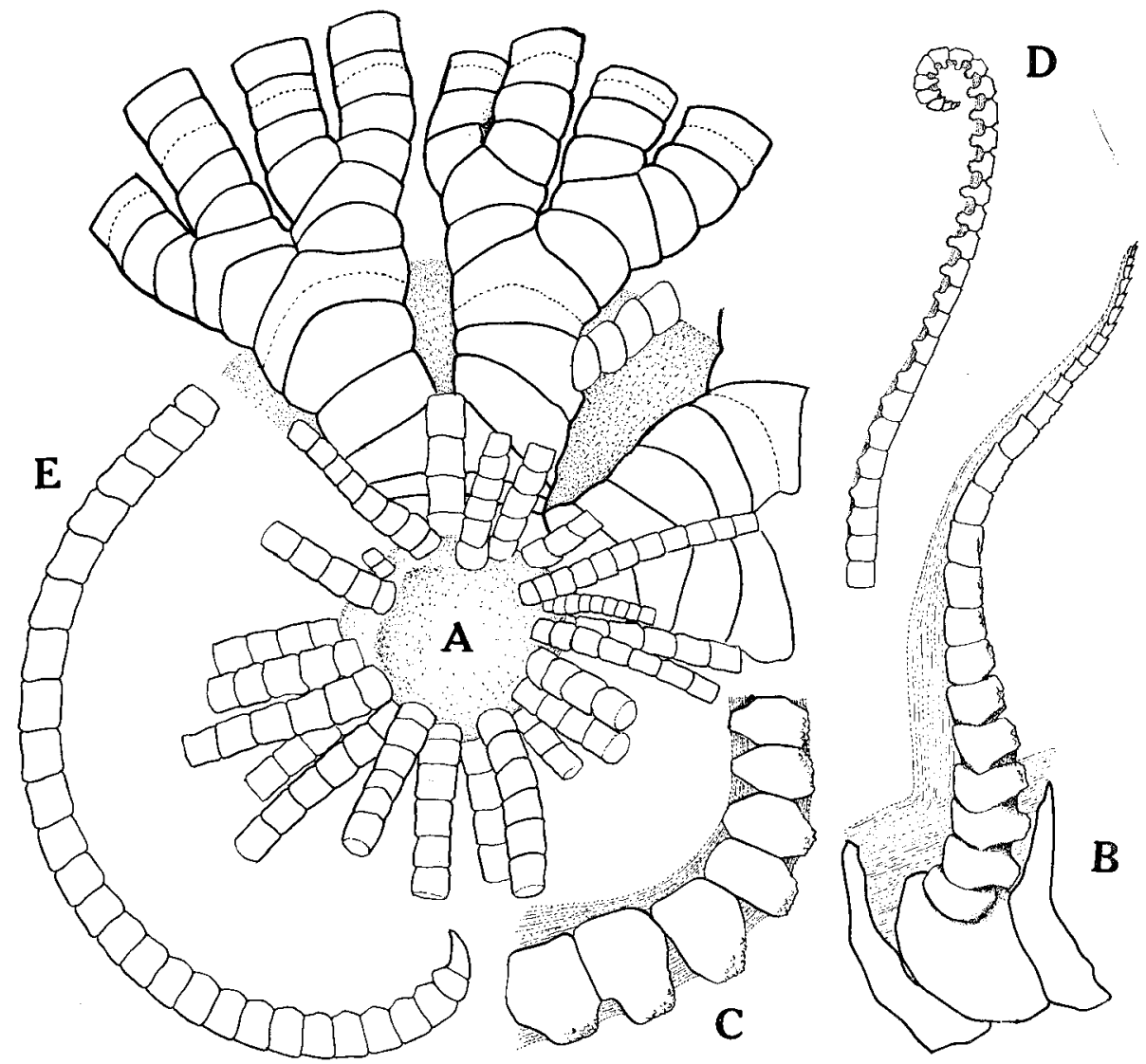

Fig. 4. Comantheria intermedia A. H. CLARK. A, Division series, $\times 5$. B, Middle pinnule, $\times 8$. C, Proximal segments of $\mathrm{P}_{1}$, dorsal protuberances, $\times 12$. $\mathrm{D}$, comb-like structure of $\mathrm{P}_{1}$, lateral side, $\times 12$. E, Cirrus, $\times 5$.

Colour: Pale yellow in spirits.

Remarks: This species is easily distinguishable from $C$. imbricata of the same genus at a glance. Imbricata has very broad and closely related division series, and rugged and stout arms. On the contrary intermedia has narrow and well-separated division series and very slender arms. 
Distribution: Sagami Bay (between Ito and Hatsushima Island), Fukuura, southward to Amoi, China. From shallow water down to about $150 \mathrm{~m}$ in depth.

\section{Comantheria imbricata (A. H. CLARK)}

(Text-fig. 5)

Comaster imbricata A. H. CLARK, 1918a, p. 306.

Comantheria imbricata A. H. CLARK, 1918, p. 43 ; -, 1921, fig. 246 ; -, 1931, p. 515, pl. 29, fig. 87 , pl. 62 , fig. 173 .

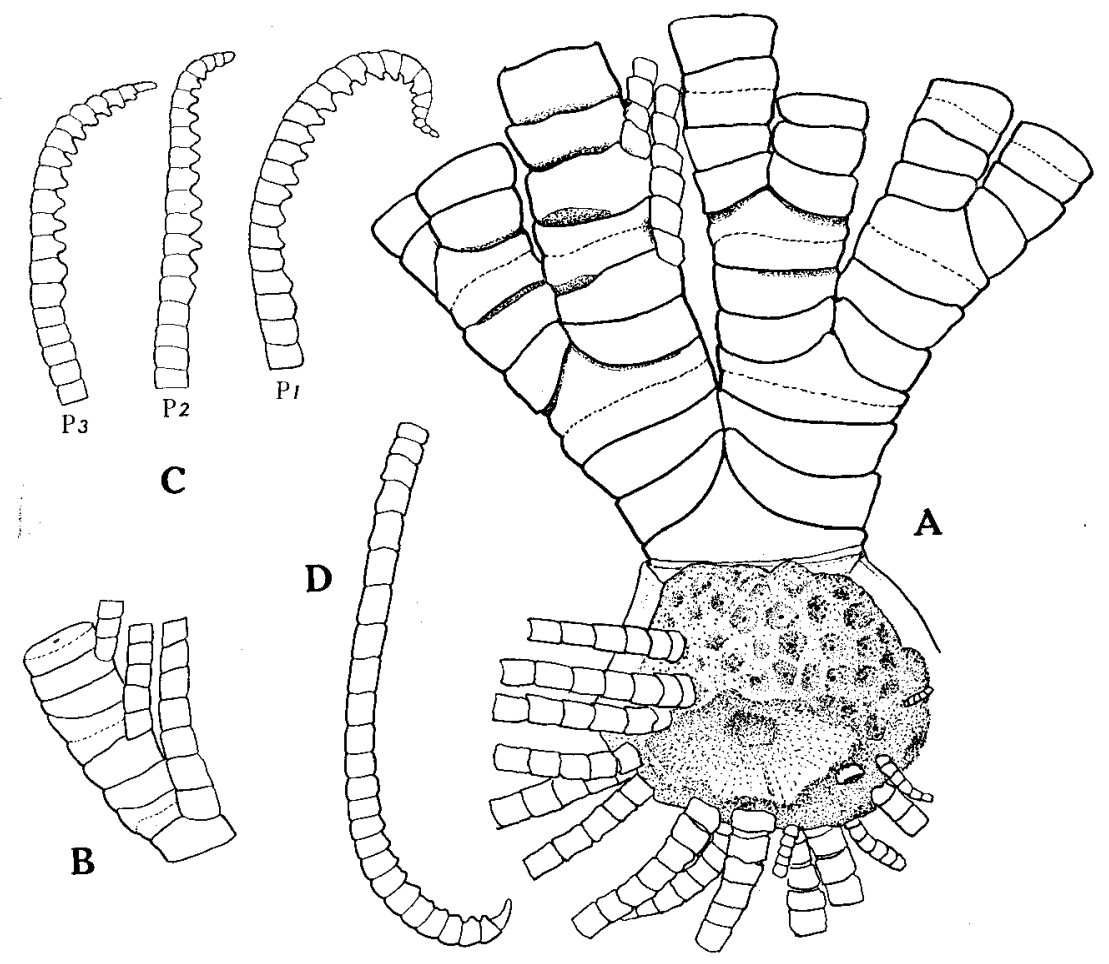

Fig. 5. Comantheria imbricata (A. H. CLARK), A, Division series, $\times 4$. B, Proximal part of the arm, $\times 3$. C, Comb-like structure of proximal pinnules, $\times 4$. D, Cirrus, $\times 2.3$.

Japanese name: Ashibuto-ohban-umishida.

Materials examined: 1 specimen; Tanabe Bay, $50 \mathrm{~m}$ deep; 26-I-1938. 1 specimen; Seto, Shirahama; IX-1939. 1 specimen; Off Minabe; coarse sandy bottom, $150 \mathrm{~m}$ deep; E. HARADA coll. ; 8-XIII-1957.

Colour: Reddish yellow in spirits.

Remarks: Comparing with C. intermedia, this species is stouter. So this is easily distinguishable from intermedia at a glance (see p. 268). 
Distribution: Southern Japan from the Korean Straits to Sagami Bay and Bonin Islands. Sublittoral, from $20 \mathrm{~m}$ down to $91 \mathrm{~m}$ in depth.

\section{Comanthus (Cenolia) japonica (MüLleR)}

(Plate XII, fig. 2)

Alecto japonica Müller, 1841, p. 186 (after CLARK, 1931)

Actinometra japonica HARA, 1895, p. 115.

Comanthus japonica A. H. CLARK, 1918, p. 49.

Comanthus solaster GISLÉN, 1922, p. 43, figs. 33, 34, and 44.

Comanthus solaster forma multicirra GISLÊN, 1922, p. 46.

Comanthus japonica GISLÉN, 1922, p. 48 ; -, 1927, p. 13.

Comanthus (Cenolia) japonica A. H. ClARK, 1931, p. 564.

Japanese name: Nippon-umishida.

Materials examined: 1 specimen; Taka-shima, Shirahama; 10-VIII-1928. 2 specimens ; Seto, Shirahama ; rocky bottom, $3 \mathrm{~m}$ deep ; I. Kogo coll.; 5-V-1961. 3 specimens ; Seto, Shirahama; rocky bottom, $2 \mathrm{~m}$ deep; I. KoGo coll.; 7-VIII-1961. 1 specimen (young form); Seto, Shirahama; rocky bottom, at the low tide mark; I. Kogo coll.; 9-VIII-1961. 4 specimens; Tô-shima, Shirahama; in a crevice of the rock, $2 \mathrm{~m}$ deep; I. KoGo coll.; 15-VIII-1961. 1 specimen; Shirasaki near Gobô City ; rocky bottom, $2 \mathrm{~m}$ deep ; I. KoGo coll. ; 29-VIII-1961. 2 specimens; Kanô-jima, Tanabe Bay; rocky bottom, $3 \mathrm{~m}$ deep; I. KoGo coll. ; 8-IX-1961. 2 specimens; Seto, Shirahama. (date unrecorded).

Biology: Most of this species were caught from the bottoms of moderate depth, average of 28 records is 76 metres (A. H. C CARK, 1931). Whereas in the coastal sea of Kii Peninsula this is regarded as a shallow water inhabitant. The animals are usually found in cracks of rock or under the rock shelves close to the shore, so far as we know, but had never been obtained from the depth of over 20 metres in this area.

Some numbers of commensals are usually found together with this animal. They are uniformly blackish brown like their host. They are two kinds of Ophiurae, Polynoidea, Harrovia elegans DE MAN, two kinds of Galathea, one of these is Galathea orientalis Stimpson, one of Macrura, and Myzostomum sp.

Colour: When alive, the arms are dull orange, the surrounding part of the centro-dorsal is dull brown, and the disk and other soft part are deep violet brown. The tips of pinnules are uniformly coloured orange, occasionally white or yellow instead of normal orange. A jetblack individual happens to be found quite occasionally.

Distribution: Southern Japanese waters from Sagami Bay (Ito, Misaki, Uraga Channel), Korean Straits to the southwest of Goto Islands, and off Kagoshima Gulf. Shore line down to $256 \mathrm{~m}$.

\section{Comanthus (Comanthus) parvicirra (MÜLLER)}

(Plate XII, fig. 3 ; Text-fig. 6) 
Alecto parvicirra MÜLlER, 1841, p. 185 (after ClARK, 1931)

Actinometra parvicirra H. L. CLARK, 1921, p. 5.

Comanthus parvicirra A. H. CLARK, 1915 (many figures); -, 1918, p. 50; -, 1921 (many figures).

Comanthus (Vania) parvicirra A. H. ClARK, 1918, p. 54 ; GISLÉN, 1922, p. 50, figs. 41-45, and p. 70.

Comaster typica GISLÉN, 1922, pp. 50, 54.

Comanthus (Vania) parvicirra comasteripinna GISLÉN, 1922, p. 4.

Comanthus parvicirra comasteripinna GISLÉN, 1922, p. 50, figs. 41-44.

Comanthus parvicirra vanipinna GISLEN, 1927, p. 51, fig. 3 .

Comanthus (Comanthus) parvicirra A. H. CLARK, 1931, p. 631.

Japanese name: Koashi-umishida.

Materials examined: 1 specimen; Seto, Shirahama; IV-1928. 1 specimen; Tôshima, Shirahama ; 4-IX-1928. 1 specimen; Kii-ohshima; VI-1937. 2 specimens, Kada, ?25-VII-1937. 2 specimens, Susami, 5-I-1951. 1 specimen; Hatakejima, Tanabe Bay; rocky shore; I. Kogo coll.; 16-V-1961. 1 specimen ; Seto, Shirahama ; rocky bottom, $5 \mathrm{~m}$ deep ; I. Kogo coll.; $16-$ V-1961. 4 specimens; Tô-shima, Shirahama; rocky bottom, $5 \mathrm{~m}$ deep; I. Kogo coll. ; 15-VIII1961. 4 specimens; Hatake-jima, Tanabe Bay; rocky bottom, $5 \mathrm{~m}$ deep; I. Kogo coll. ; 8-IX1961. 3 specimens; Kanô-jima, Tanabe Bay; rocky bottom, $3 \mathrm{~m}$ deep; I. Kogo coll.; 8-IX1961 .

Description: (on a medium-sized specimen) The centro-dorsal is $4 \mathrm{~mm}$ in diameter and pentagonal, and strongly reduced in height subsiding to the level of the basals. The free dorsal area with a central pit is $3 \mathrm{~mm}$ across, flat and smooth. The cirri are arranged in a single row on the periphery of the centro-dorsal, very fragile, 16 in number. A moderate-sized cirrus is $6.5 \mathrm{~mm}$ in length and composed of 12 segments. On the dorsal side of each cirrus a transverse ridge appears after the 6 th or 7 th segments.

The disk is $15 \mathrm{~mm}$ in diameter without calcareous deposition. The anal cone is $3.5 \mathrm{~mm}$ in height, at the center of the disk.

The division-series are well separated laterally. IBr-series are all $2, \mathrm{IBr}-$ series $4(3+4)$ in 9 cases and 2 in an exceptional case, IIIBr- and IVBr-series are all $4(3+4)$.

Arms are 39 in number, $60-120 \mathrm{~mm}$ long. Syzygies of the arm occur $3+4$, and $15+16$, after these at a interval of 4 muscular articulations. The pinnule of IIBr-series is composed of 36-43 segments, 9-12 mm long with a comb-like structure of $8-10$ teeth. The next pinnule composed of 34-39 segments, 9-11 mm long with 7-9 teeth. $\mathrm{P}_{1}, 27-35$ segments, 5-9 mm long with 8 teeth. $P_{2}, 16-25$ segments, 3-6 $\mathrm{mm}$ long with 8 teeth. $P_{m}, 7-9 \mathrm{~mm}$ long without tooth. The segments of the arm provided with minute spines on the distal edge are slightly overlapping to the next segment.

Biology: This species is very abundant in the vicinity of Shirahama. The animals are found in the small hole of the rocky bottom near the shore and used to be collected from tide-pool. In natural habitat they put the bodies under the rock shelves and stretch out their arms only. The arms 
are used for fixing their bodies to the bottom as their cirri are greatly - reduced. This is a very nervous animal. For instance, the animal tends to escape from a right and temporary shock by hand and runs into more interior place of the hole in a hurry. Since their arms are very fragile, the tendency to autotomize is very conspicuous in this species. When the stimulation is too strong for them, the animals detach not only their whole arms but also the disk in which the internal organs are enclosed from the body.

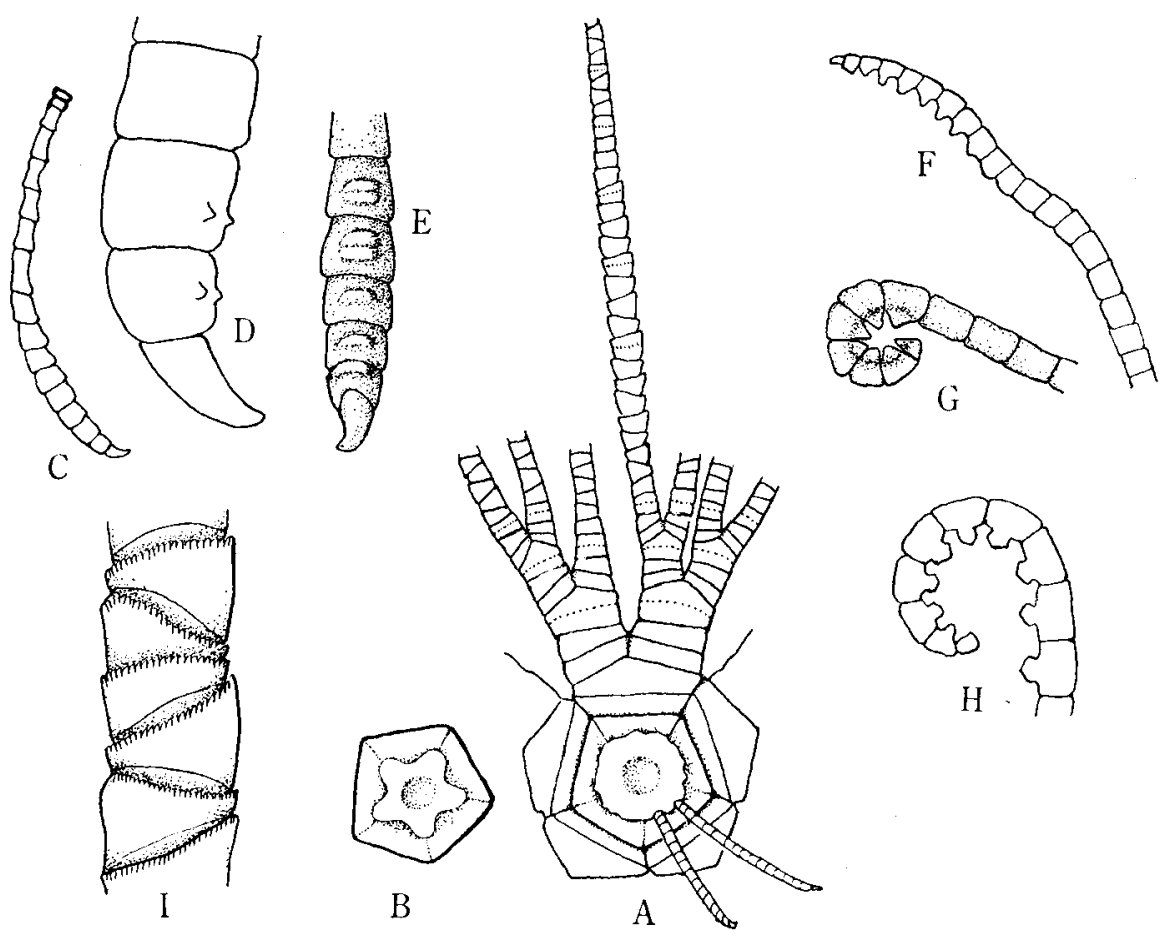

Fig. 6. Comanthus (Comanthus) parvicirra (MülleR). A, Dorsal view, with a round centro-dorsal, $\times 2$. B, A petaloid centro-dorsal, $\times 2$. C, Cirrus, $\times 6$. D and $\mathrm{E}$, showing dorsal protuberances $(\mathrm{D}, \times 20$ and $\mathrm{E}, \times 10), \mathrm{F}-\mathrm{H}$, Showing comb-like structures in proximal pinnules $(\mathrm{F}, \times 6, \mathrm{G}, \times 9, \mathrm{H}, \times 10) . \mathrm{I}$, Segments of distal arm, $\times 10$.

A small number of parasitic animals are frequently found. They are one of Polynoid species, one of Synalpheus (or Alpheus), Harrovia elegans DE MAN, Myzostomum sp., Myzostomum costatum LEUCKART and Ophiomastix mixta LüTKEN. These are generally violet-brown in colour similar to their host.

Colour: When alive, it is normally violet-brown at most of the body. The colour gradually becomes lighter along the arm, and entirely changes into lemon-yellow or reddish-yellow at the distal part of the arm. This point 
is one of the characteristics in this species. But various colour variants may be found occasionally (See Pl. XII, fig. 3). In spirits uniformly yellowish brown.

Remarks: Comanthus (Comanthus) timorensis and C. (C.) parvicirra are included in the subgenus Comanthus. According to CLARK (1931), timorensis is easily distinguished from parvicirra by possessing more than 30 arms in number. Whereas in our specimens the number of arms varies from 20 to 60,37 on an average of 20 specimens. We studied our specimens about some basic characters such as the length, the number, and the shape of each part of the body, but we could not find any distinction in these morphological characters excepting the number of arms. So we had concluded that all our specimens are regarded as parvicirra as described by GISLÉN (1922 and 1927).

Distribution: Widely distributed in the Indo-West Pacific region from Madagascar, Mauritius, the Seychelles, and Baluchistan to Australia, southward to Fremantle on the west and Moreton Bay on the east, New Caledonia, Fiji, Tonga, the Gilbert, Caroline, Pelew, and Bonin Islands, southern Japan (Tokyo Bay, Misaki, and Okinose), Formosa and Amoi, China. From the low tide mark down to $110 \mathrm{~m}$. Most of the records are from very shallow waters.

\section{Superfamily Mariametrida GISLÉN}

Family Zygometridae A. H. CLARK

\section{Catoptometra magnifica A. H. CLARK}

Catoptometra magnifica A. H. CLARK, $1908 \mathrm{c}$, p. $208 ;-, 1918$, p. 63 ; -, 1941, p. 126, pl. 7, figs. 24-25, pl. 8, fig. 26, pl. 9, fig. 31; GISLÉN, 1922, p. 17.

Catoptometra magnifica var. minor GISLÉN, 1922, pp. 4, 65, 67, fig. 47; 一, 1927, pp. 2, 20, 68, and 69.

Japanese name: Ohkobu-umishida.

Materials examined: 2 specimens; Kii-Ohshima; depth unrecorded; 25-VII-1937.

Remarks: This is one of the largest species in the sea of Kii Peninsula. It reaches more than $450 \mathrm{~mm}$ in diameter when the arms are stretched.

Colour: The arms and cirri are yellow-brown, and the remaining parts of the body are uniformly dull brown in spirits.

Distribution: This occurs in the sea of southern Japan, off Goto Islands, Korean Straits, and Sagami Bay, southward to Bonin Islands, Philippines, southern Annam, and Lesser Sunda Islands. From $36 \mathrm{~m}$ down to $914 \mathrm{~m}$ in depth.

Family Mariametridae A. H. ClaRK

7. Liparometra grandis (A. H. CLARK) 
Himerometra grandis A. H. CLARK, 1918b, p. 222.

Liparometra grandis A. H. CLARK, 1918, p. 103 ; GISLÉN, 1922, pp. 74, 182, figs. 85 and 86.

Japanese name: Tsuya-umishida (nom. nov.).

Materials examined: 2 specimens; Kii-Ohshima; depth unrecorded ; 25-VII-1937.

Colour: Uniformly red-brown in spirits.

Remarks: The expansion of arms reaches to more than $300 \mathrm{~mm}$ in diameter. This resembles Catoptometra magnifica of the family Zygometridae in appearance, but is apparently distinct in the articulation of two segments of $\mathrm{IBr}$-series. In Catoptometra magnifica these two segments are connected by syzygy; on the contrary, they are connected by synarthry in this species.

Distribution: This is known only from the Bonin Islands and southern Japan (Hirado and Misaki). From the littoral down to $37 \mathrm{~m}$ at least.

\section{Lamprometra parmata parmata (MÜLLER)}

(Plate XII, fig. 4 ; Text-fig. 7)

Alecto parmata MüLlER, 1841, p. 185 (after ClARK, 1941)

Lamprometra protectus A. H. CLARK, 1918, pp. 100, 271, pl. 8 (in colour), pl. 10, figs. 99-100; -, GISLËN, 1922, p. 75.

Lamprometra brachypecha H. L. CLARK, 1921, pp. 23 and 192.

Lamprometra parmata parmata A. H. CLARK, 1915, figs. 259 and 477 ; -, 1921, figs. 49, 50, $250,472,473$, and $720 ;-, 1941$, p. 474 , pls. 53-55, figs. 243-257.

Japanese name: Higasa-umishida.

Materials examined: 2 specimens; Tsuya-jima near Shiono-misaki, $50 \mathrm{~m}$ deep ; 31-III1929. 2 specimens; Seto, Shirahama; 15-IX-1928. 4 specimens; Seto, Shirahama; found crowded on the rocky bottom of $3 \mathrm{~m}$ deep; E. HARAdA and I. Kogo coll.; 7-VII-1961. 2 specimens; Kanô-jima, Tanabe Bay; found crowded, $3 \mathrm{~m}$ deep; I. KoGo coll.; 15-VIII-1961. 5 specimens; Kanô-jima, Tanabe Bay; in crowds, $3 \mathrm{~m}$ deep; I. KoGo coll.; 8-IX-1961. 4 specimens, without any records.

Description: The centro-dorsal is $5 \mathrm{~mm}$ in diameter, thick discoidal. The free dorsal area is $2.8 \mathrm{~mm}$ across, flat and rounded with a circle of carination. The cirri are 51 in number, composed of 20-28 (aver. 24-26) segments, 9-18 (mostly 13-15) $\mathrm{mm}$ long and arranged in 2 or 3 whirls. Longitudinal carinations are visible on the dorsal surface of distal cirrus.

The disk is $22 \mathrm{~mm}$ in diameter. The anal cone is $7 \mathrm{~mm}$ in height, subcentral and interradial on the disk. The mouth is central. A great number of calcareous depositions are found in the epidermis of disk. The ambulacral grooves are entirely closed.

The division series are all 2 . The arms are 46 in number, $52-80 \mathrm{~mm}$ long, slender. Syzygies occur at $3+4$, from $7+8$ to $14+15$ on the second place, distally at intervals of 9-12 muscular articulations. Pinnules (see the following remarks). 
Biology: This species, in natural condition, tends to assemble together on a flat rock and never escape into rock cave. Following to a current of water, the animal can swim and migrate.

Colour: When alive, a ring-shaped pattern by bicolour consisting of pale brown and red purple on the ventral side of body is observed. This is characteristic to this species. In spirits, the disk is greyish red-purple,

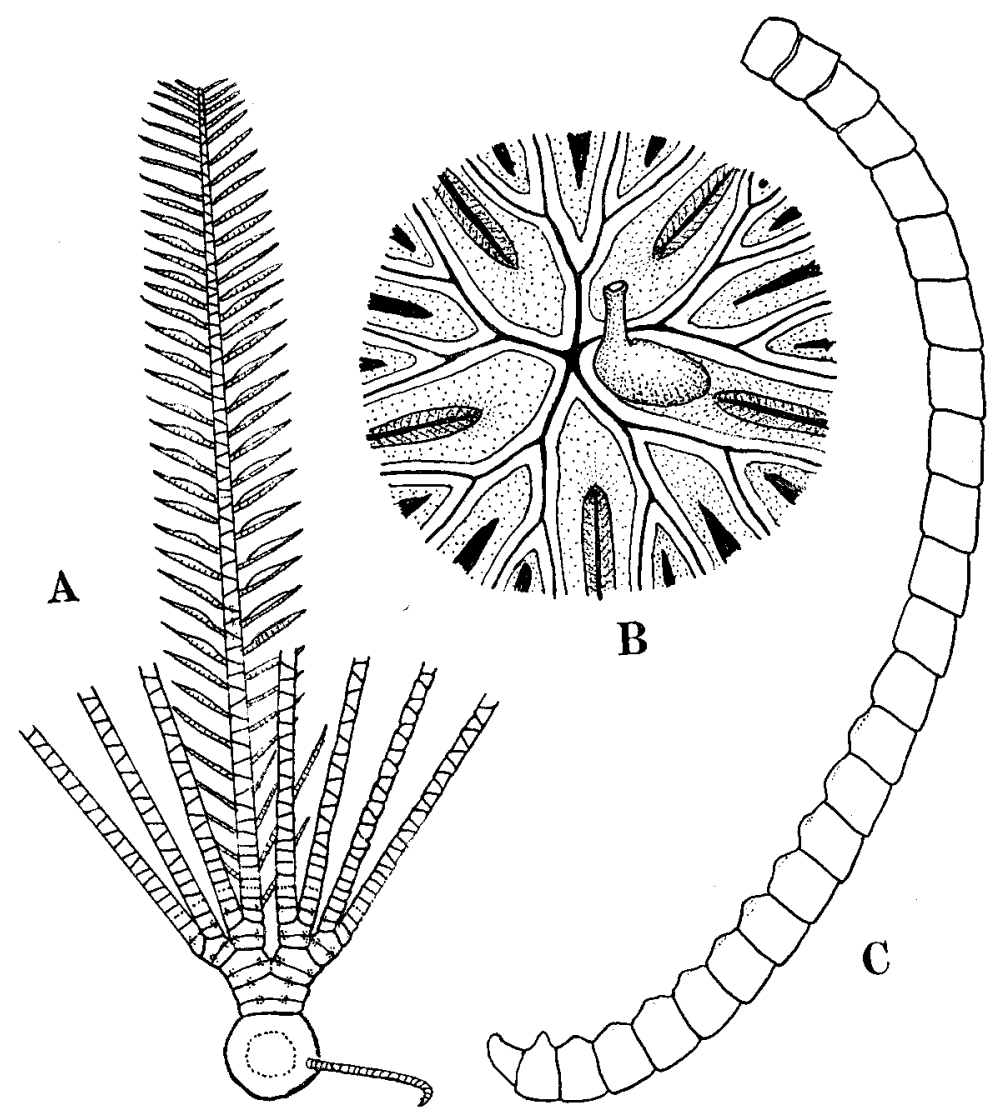

Fig. 7. Lamprometra parmata parmata (MüLleR). A, Dorsal view, $\times 1.2$. B, Disk, $\times 2$. C, Cirrus, $\times 8$.

the centro-dorsal and the cirri are brown, and the arms are dark brown.

Remarks: At first we had a suspicion that these might be the young forms of Liparometra grandis belonging to the family Mariametridae, because of the similarity in appearance of both forms. According to A. H. Clark (1941), three genera of this family, Liparometra, Lamprometra and Dichrometra, are very closely allied. Therefore, he could not help adopting the minute 
differentiations of the proximal pinnules in his keys to the genera and also to the species, we suppose.

Between both species occurring in the sea of Kii Peninsula, a comparison for their proximal pinnules is given as follows:

Liparometra grandis

$P_{1}$ about 30 segments, about $13 \mathrm{~mm}$ long

$\mathrm{P}_{2}$ about 30 segments, $14-16 \mathrm{~mm}$ long

$\mathrm{P}_{3}$ 33-35 segments, $18 \mathrm{~mm}$ long

$\mathrm{P}_{4}$ 23-27 segments, 13-18 $\mathrm{mm}$ long
Lamprometra parmata 34-38 segments, $8-10 \mathrm{~mm}$ long 26-33 segments, $14-18 \mathrm{~mm}$ long 12-15 segments, $5-6 \mathrm{~mm}$ long about 10 segments, $3-5 \mathrm{~mm}$ long

The fact that $P_{1}$ is composed of much minute segments in Lamprometra is regarded as a characteristic feature enough to be discerned each other.

Distribution: This is new to Japan. Hitherto known from Hongkong, Philippines to the Caroline, Marshall, Hawaiian Islands, Fiji, Tonga Islands, New Caledonia, Solomon Islands, Torres Strait, and westward to Baluchistan. From the shore down to $51 \mathrm{~m}$ deep.

\section{Family Colobometridae A. H. Clark \\ 9. Iconometra japonica (HARTLAUB)}

Antedon japonica HARTLAUb, 1890, p. 172 (after Clark, 1947)

Oligometra japonica A. H. CLARK, 1918, p. 130 ; GISLEN, 1927, p. 29, figs. 19-22.

Iconometra japonica A. H. CLARK, 1947, p. 94 , pls. $10-11$ and 26 , figs. 53-56 and 134-135.

Japanese name: Shimofuri-umishida (nom. nov.).

Materials examined: 1 specimen; Shisô-jima, of Tanabe Bay; no further records ; VI1922. 2 specimens; Shisô-jima, of Tanabe Bay; rocky bottom of $12 \mathrm{~m}$ in depth; found clinging to a Gorgonacean species, Melithaea flabellifera (KüKENThaL); H. INAGAKI coll. 9-VIII-1961.

Colour: When alive, the body is uniformly reddish brown and has scattering white spots on the ventral side of the body.

Biology: This is generally found with Gorgonacean species clinging by the cirri. In aquarium, the animal often swims and rises to the surface of water by beating its arms alternately.

Distribution: Confined to southern Japanese waters, definitely known from Sagami Bay only. From the shallow water down to $46 \mathrm{~m}$ in depth.

\section{Cyllometra manca (CARPENTER)}

(Text-fig. 8)

Antedon sp. CARPenter, 1879, p. 384 (after Clark, 1947).

Cyllometra albopurpurea A. H. CLARK, 1918, p. 115 ; GISLÉN, 1922, pp. 4, 6, 7, 78, 82, 183, figs. 64-65; -, 1927, pp. 2, 25, 69, 
Cyllometra solluta A. H. CLARK, 1918, p. 115 ; GISLÉN, 1927, p. 26.

Cyllometra disciformis A. H. CLARK, 1918, pp. 114 and 116; GISLÉN, 1922, pp. 4-7, 9, 77, 84, 180, and 181, figs. 68-69.

Cyllometra pulchella GISLÉN, 1922, pp. 4, 6, 9, 10, 84, 110, 131, 180, and 181, figs. 133-140, pl. 1 , fig. $9 ;-, 1927$, pp. $2,23,25,26$, and 68 .

Cyllometra manca A. H. CLARK, 1915, p. $54 ;-, 1918$, pp. 115, 116 and 276 ; -, 1921, p. 147 ; 一, 1947 , p. 137 , pls. $17-22$, figs. 86-108; GISLÉN, 1922, pp. 4, 6, 7, 79, 80, 181, figs. 66$67 ;-, 1927$, pp. 2, 25, 69 .

Japanese name: Shima-umishida.

Materials examined: 1 specimen; Hikimoto (exact location unknown); by trawl-net; 18-IV-1928. 1 specimen; Tonda, Shirahama; rocky shore; 21-V-1928. 25 specimens; Kada, near Wakayama City; no further records; VII-1935. 1 specimen; off Minabe; by trawl-net; III-1950.

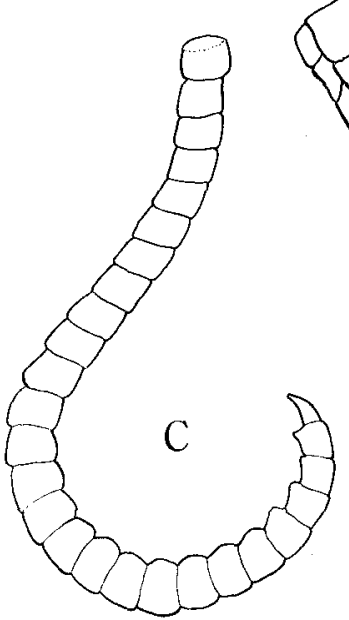

Fig. 8. Cyllometra manca (CARPENTER). $\times 12$. C, Cirrus, $\times 10$.

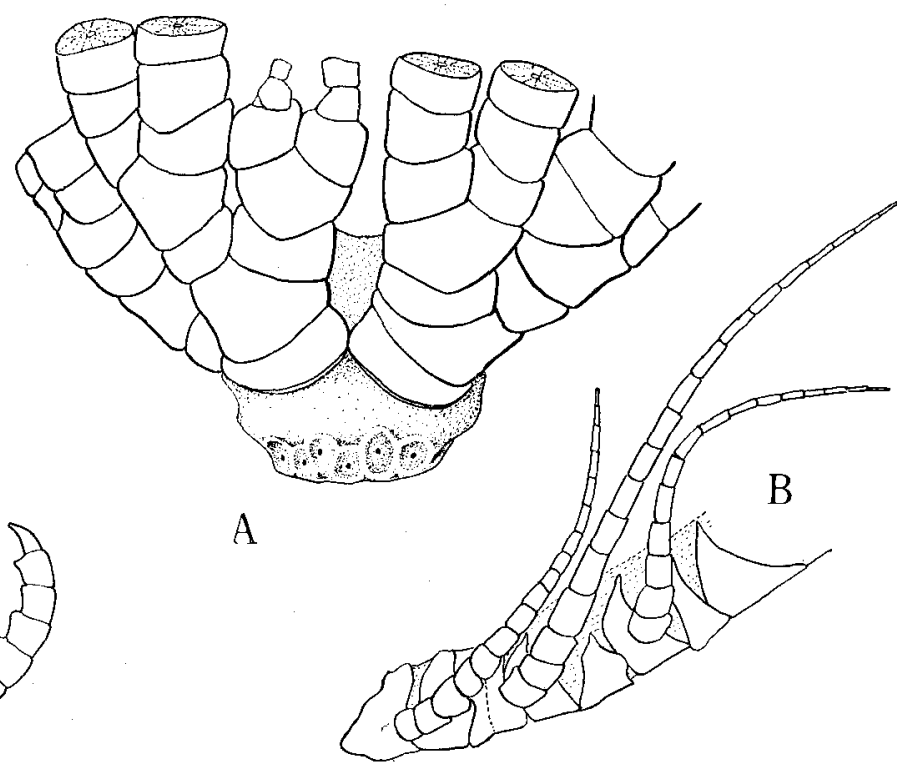

A, Lateral view, $\times 8$. B, Proximal pinnules,

Colour: In spirits the central part of body is almost white, gradually becomes to red-violet along the arms distally, and the arms are coloured by narrow and transverse bands of yellow.

Distribution: Distributed widely in the Indo-West Pacific region from Philippines, Kei, and Lesser Sunda Islands, and westward to the Persian Gulf, and also in southern Japanese waters from Tokyo Bay, Uraga Channel, Suruga Gulf, Sagami Bay (Ose-zaki, Suno-saki, Misaki, between Ito and Hatsushima, and Iagoshima) to off Nagasaki and Hirado, Gotô Islands, off Kagoshima, southward to Okinawa, From the depth of 22(?15) $\mathrm{m}$ down to $329(? 729) \mathrm{m}$, 


\section{Decametra parva (A. H. CLARK)}

Prometra parva A. H. ClARK, 1912a, p. 39.

Decametra parva A. H. ClARK, 1918, p. 121, pl. 20, fig. 46; -, 1947, p. 195, pl. 22, fig. 113.

Japanese name: Chibi-torafu-umishida (nom. nov.).

Materials examined: 14 specimens; Tsuri-jima (exact location unknown), $54 \mathrm{~m}$ deep; 3-III-1929.

Colour: The perisomic area is deep brown and the rest is almost white in spirits.

Distribution: This is known from southern Japan, Gotô Islands, Korean Straits, southward to the Kei Islands, and the Java Sea. From shore line down to $90 \mathrm{~m}$ deep.

\section{Superfamily Tropiometrida A. H. Clark}

Family Tropiometridae A. H. CLARK

\section{Tropiometra afra macrodiscus (HARA)}

Antedon macrodiscus HARA, 1895, p. 115; HARA and OKADA, 1921, p. 33 ; GISLÉN, 1922, p. 9. Tropiometra macrodiscus A. H. ClaRK, 1918, pp. iv, 131 ; GIsLEN, 1922, p. 92.

Tropiometra afra var. macrodiscus GisLÉN, 1922, p. 90 ; MINoBE, 1930, p. 110.

Tropiometra encrinus GISLÉN, 1922, p. 92, figs. 70-71.

Tropiometra afra macrodiscus GISLÉN, 1922, pp. 7, 91 and 93; A. H. ClaRK, 1947, p. 272, pl. 32, fig. 169 (figures to be referred to 1915 , and also 1921).

Japanese name: Oh-umishida.

Materials examined: 2 specimens; Kii-Ohshima; no further records ; VII-1937. 1 specimen ; Naka-jima, Tanabe Bay ; rocky bottom, 5 m deep ; I. Kogo coll. ; 24-VIII-1961. 1 specimen ; Kanô-jima, Tanabe Bay; rocky bottom, $3 \mathrm{~m}$ deep ; I. KoGo coll. ; 8-IX-1961.

Colour: Uniformly deep red-brown in spirits. When alive, the animal is so deep in colour that it looks like quite jetblack. Occasionally, there are found the individuals coloured chrome-yellow, apparently a colour variant of the same species.

Biology: Under the sea the animals stand stretching its arms upwards and anchoring tightly by its rigid cirri on a rock where a current flows swiftly. In contrast to Comanthus (Cenolia) japonica and C. (Comanthus) parvicirra the arms of this species are very strong, so the animal seldom cuts off its arms even when strongly touched for collecting in the sea.

Distribution: This occurs from Hong Kong northward to Korean Straits and eastward to Sagami Bay, and Bonin Islands. From the low tide mark down to 66(? 919) $\mathrm{m}$ in depth; 
Family Calometridae A. H. Clark

13. Pectinometra flavopurpurea (A. H. CLARK)

(Text-fig. 9)

Antedon flavopurpurea A. H. CLARK, 1907, pp. 131 and 134.

Pectinometra flavopurpurea A. H. CLARK, 1918, p. 138; -, 1947, p. 379, pl. 39, figs. 199-200; GISLÉN, 1922, pp. 5, 97 and 181, figs. 72-73;-, 1927, pp. 2, 32, and 69.

Japanese name: Hane-umishida. (nom. nov.).

Materials examined: 1 specimen; Seto, Shirahama; no further records; XI-1922.
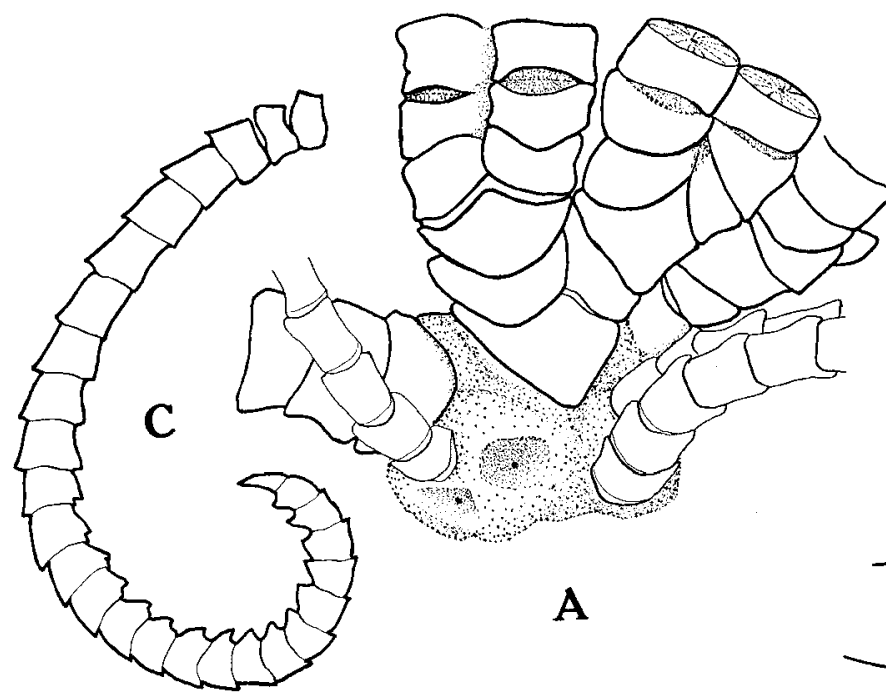

A

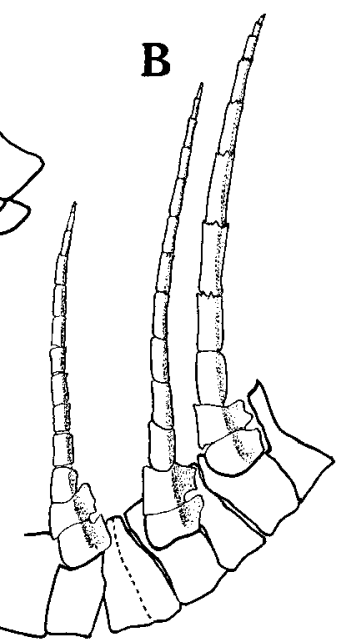

Fig. 9. Pectinometra flavopurpurea (A. H. CLARK). A, Lateral view, $\times 10$. B, Proximal pinnules, $\times 8$. C, Cirrus, $\times 10$.

Colour: Almost white in spirits. It has been preserved for so long time that its original colour seems to be lost.

Distribution: This is known only from southern Japanese waters; off Kagoshima Gulf, Suruga Gulf, Sagami Bay (Ose-zaki, Okinose, and Misaki), and Uraga Strait. From sublittoral down to 115 (? 115-375) $\mathrm{m}$ in depth.

\section{Calometra callista (A. H. C C LARK)}

(Text-fig. 10)

Antedon callista A. H. CLARK, 1907, pp. 132 and 135.

Calometra callista GIsLÉN, 1922, p. 96 ; A. H. CLARK, 1947, pp. 390-393, pl. 36, fig. 193.

Japaneșe name; Yụbi-umișhida (nom, nov.). 
Material examined: 1 specimen; off Minabe; by trawl-net, probably from over $150 \mathrm{~m}$ in depth; III-1950.

Colour: Pale brown in spirits.

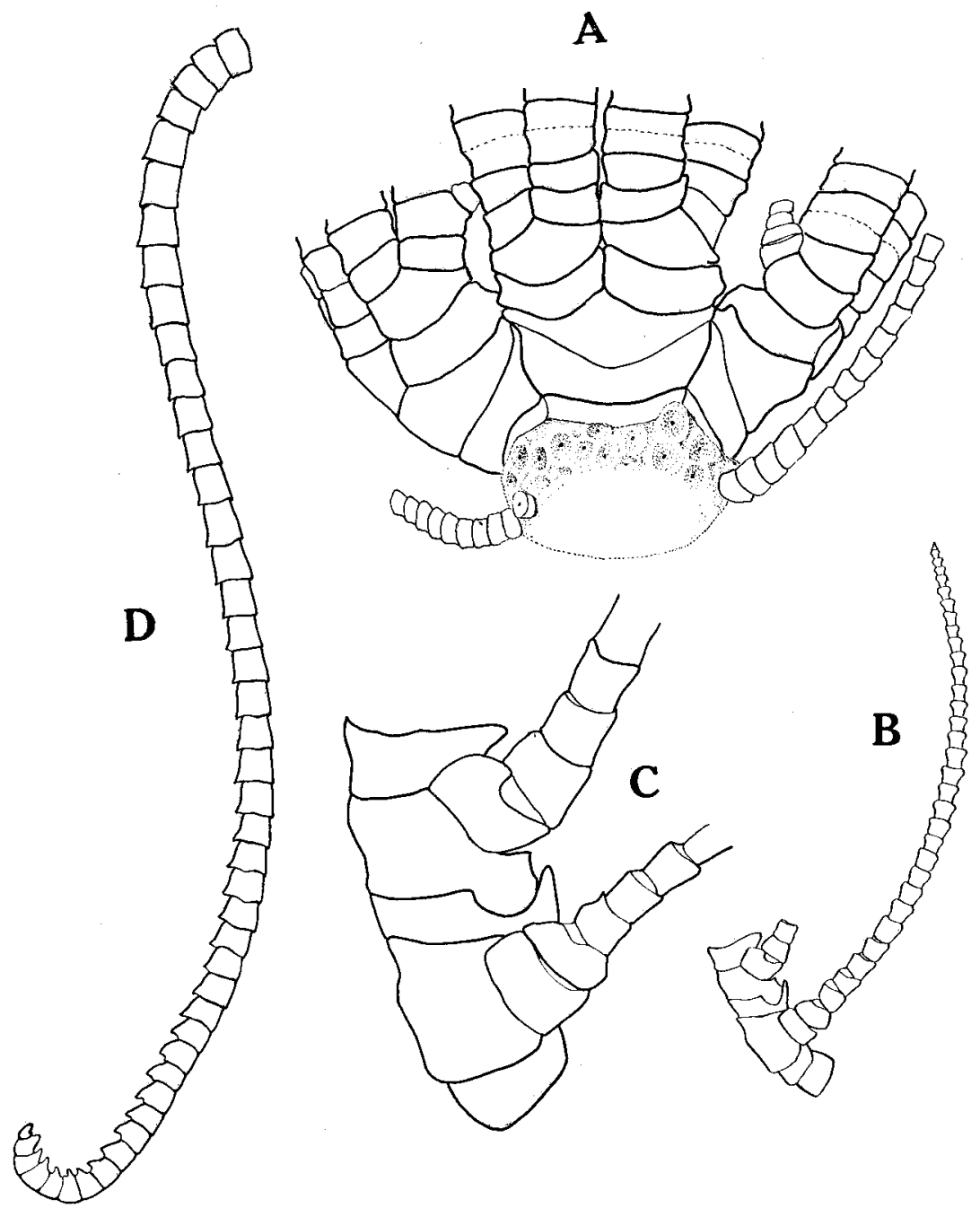

Fig. 10. Calometra callista (A. H. CLARK). A, Lateral view, $\times 6, \quad B, \mathrm{P}_{1}, \times 10$. C, Proximal segments from $B, \times 20$. D, Cirrus, $\times 6$.

Distribution: This occurs in southern Japanese waters ; west of Nagasaki, southwest of Gotô Islands, off Kagoshima Gulf, and Sagami Bay. From 100 to 195 (? 254) $\mathrm{m}$ in depth. 
Family Thalassometridae A. H. CLARK

15. Stenometra diadema (A. H. CLARK)

(Text-fig. 11)

Antedon diadema A. H. ClARK, 1907, p. 144.

Stenometra dorsata A. H. CLARK, 1918, p. 157.

Stenometra diadema A. H. CLARK, 1918, p. 156 ; GISLEN, 1922, p. 118; -, 1927, pp. 3, 39, and 69 , figs. 34 and 35.

Japanese name: Kin-umishida.

Material examined: 1 specimen; off Minabe; by trawl-net, presumably about $150 \mathrm{~m}$ deep ; III-1950.

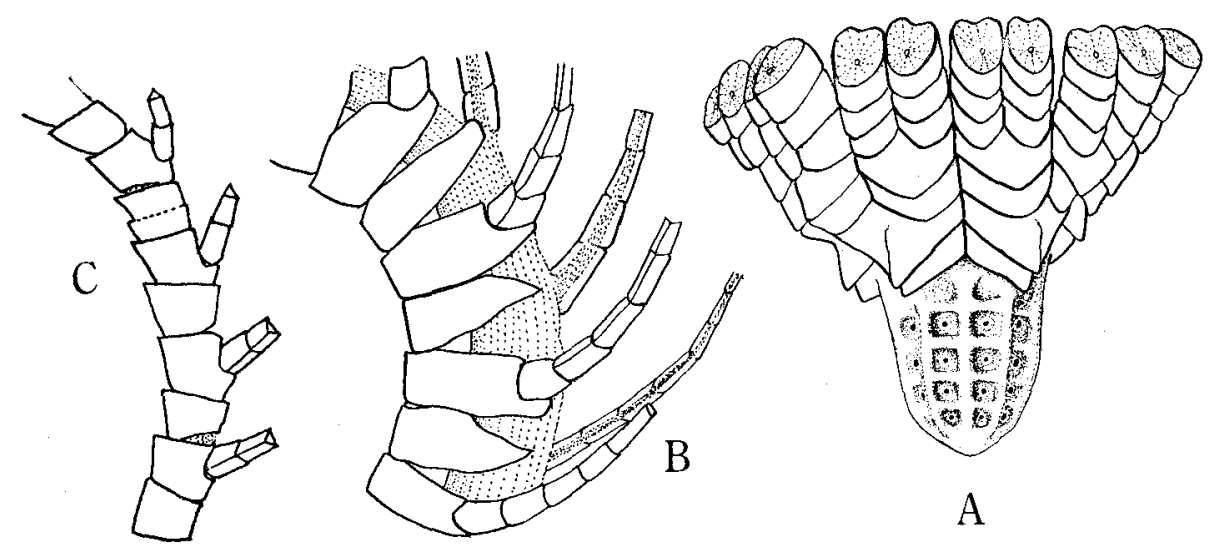

Fig. 11. Stenometra diadema (A. H. CLARK). A, Lateral view, $\times 5 . \quad B$, Some of proximal pinnules, $\times 8$. $\mathrm{C}$, Distal arm, $\times 8$.

Colour: The soft parts of body are pale brown and the rest are almost white in spirits.

Distribution: Found in southern Japanese waters from Korean Straits to Sagami Bay. From the depth of 141 (? 95) down to $311 \mathrm{~m}$.

\section{Suborder Macrophreata A. H. CLARK \\ Family Antedonidae A. H. CLARK \\ Subfamily Antedoninae A. H. ClarK \\ 16. Compsometra serrata (A. H. CLARK)}

Antedon serrata A. H. ClARK, 1908d, p. 241, pl. I, fig. 4.

Compsometra serrata A. H. CLARK, 1918, p. 209 ; -, 1921, pp. 221, 227, 229, 527, 581, and 595, figs. 296, 335, and 342; GISLÉN, 1922, p. 126, figs. 105-108; -, 1927, p. 43. 
Japanese name: Togebane-umishida.

Material examined: 1 specimen; on the north coast of Seto-zaki, Shirahama; found on an Alcyonacean species; H. UTINOMI coll.; 22-IV-1952.

Colour: Yellowish white in spirits.

Distribution: Tokyo Bay, Misaki, southward to Formosa. From the low tidal mark down to $63 \mathrm{~m}$ in depth.

\section{Eumetra aphrodite (A. H. CLARK)}

(Text-fig. 12)

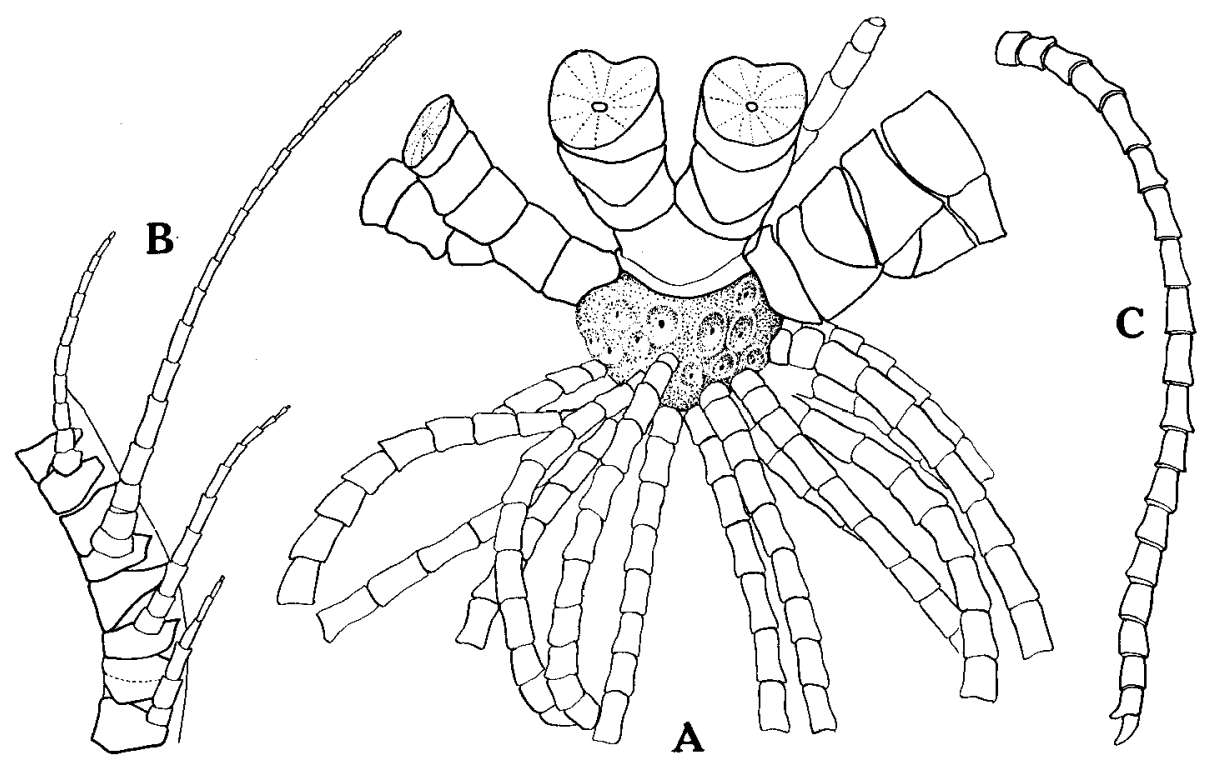

Fig. 12. Eumetra aphrodite (A. H. CLARK). A, Lateral view, $\times 7$. B, Proximal pinnules, $\times 5$. C, Cirrus, $\times 5$.

Iridometra (Eumetra) aphrodite A. H. CLARK, 1912, p. 137.

Eumetra aphrodite A. H. CLARK, 1918, p. 213; GISLÉN, 1927, p. 45, figs. 38-39.

Japanese name: Hishibushi-umishida (nom. nov.).

Material examined: 1 specimen; Hikimoto (exact location unknown); by trawl-net; depth and coll. unrecorded; 18-IV-1926.

Colour: The soft part of body is brown, and the rest pale brown in spirits.

Distribution: This is known from Sagami Bay (Misaki) and Lesser Sunda Islands. From the depth of $36 \mathrm{~m}$ down to $73 \mathrm{~m}$. 
Subfamily Perometrinae A. H. CLARK

18. Perometra diomedeae (A. H. $\mathrm{C}_{\mathrm{LARK}}$ )

(Text-fig. 13)

Antedon diomedeae A. H. ClARK, 1907, p. 146.

Perometra diomedeae A. H. ClARK, 1915, p. 329, figs. 13, 112, 387, 431, and 503; -, 1918, p. 234 ; -, 1921, pp. 39, 56, and others, figs. 82-84, 119, 319, and 772; GISLÉN, 1927, p. 48.

Japanese name: Tsuno-umishida.

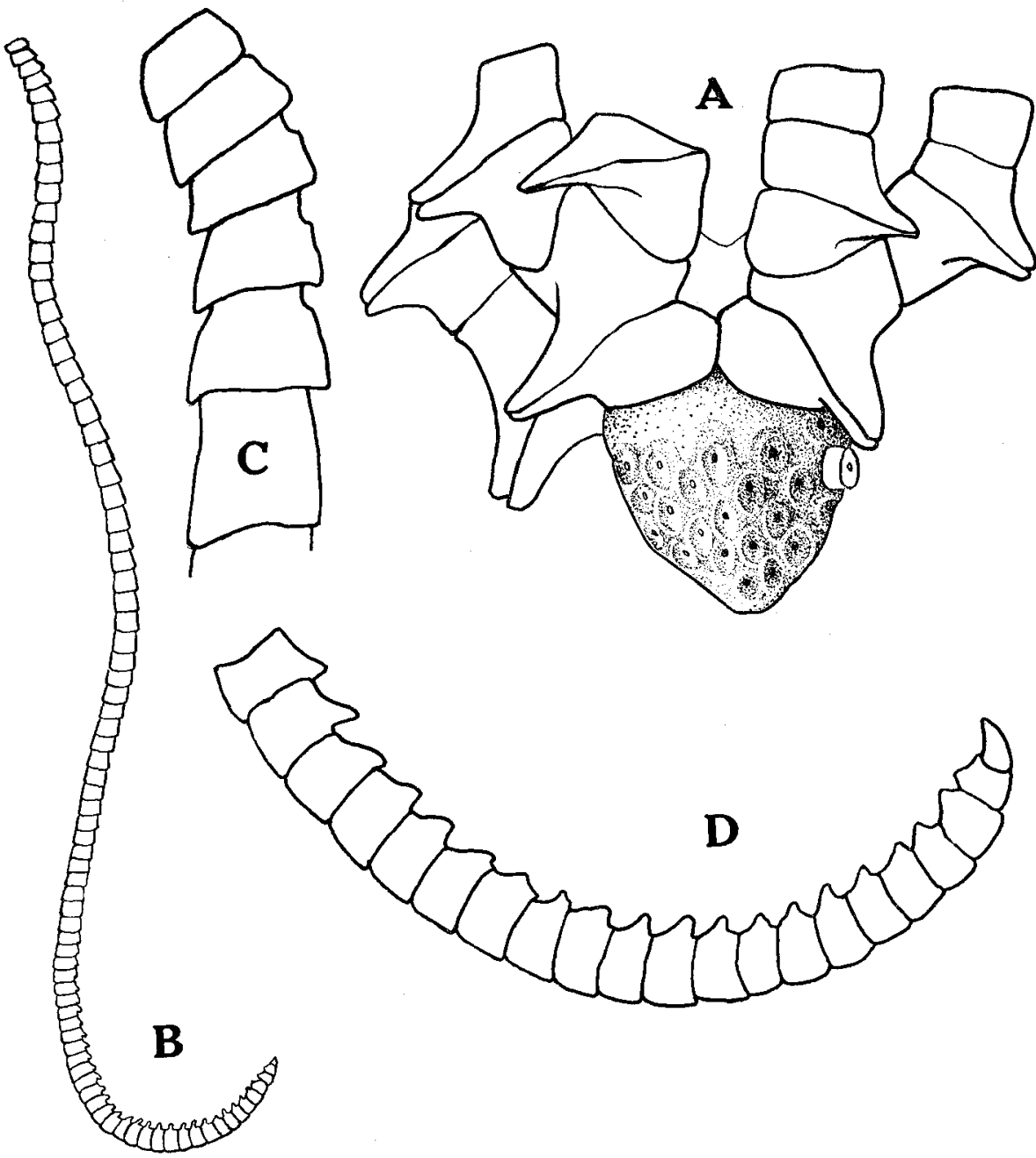

Fig. 13. Perometra diomedeae (A. H. CLARK). A, Lateral view, $\times 9 . \quad B$, Cirrus, $\times 5$. C, Proximal part of cirrus, $\times 14$. D, Distal part of cirrus, $\times 14$. 
Material examined: 1 specimen; off Minabe; by trawl-net, from the depth over $100 \mathrm{~m}$; III-1944.

Colour: White in spirits.

Distribution: Occurs in southern Japanese waters from Korean Straits to Sagami Bay. From $70 \mathrm{~m}$ down to 250 (? 273) $\mathrm{m}$ in depth.

\section{Erythrometra rubra (A. H. CLARK)}

(Text-fig. 14)

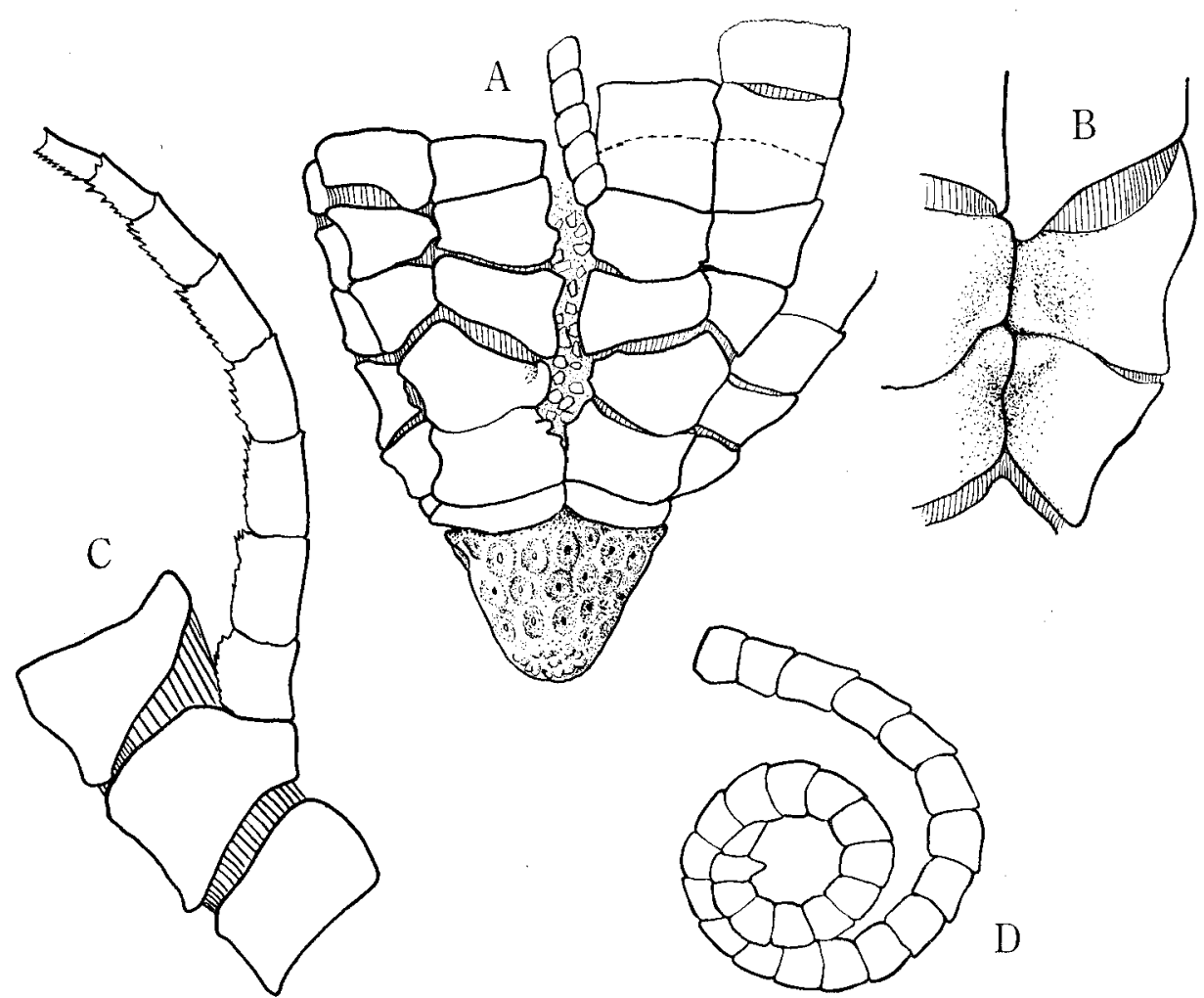

Fig. 14. Erythrometra rubra (A. H. CLARK). A, Lateral view, $\times 9 . \quad$ B, Lateral protuberances of proximal segments of the arm, $\times 18$. C, Proximal segments of $\mathrm{P}_{1}, \times 18 . \mathrm{D}$, Cirrus, $\times 18$.

Antedon ruber A. H. CLARK, 1907, p. 146.

Erythrometra ruber A. H. CLARK, 1918, p. $236 ;-$, 1921, p. 53, figs. 78, 88, 666, 667, and 753. Erythrometra rubra GisLÉN, 1922, p. 140, figs. 150-152; -, 1927, p. 48, fig. 40.

Japanese name: Aka-umishida (nom. nov.).

Material examined: 1 specimen; off Minabe; by trawl-net, probably over $100 \mathrm{~m}$ in depth ; III-1950. 
Colour: Pale reddish white in spirits.

Distribution: Confined to southern Japan only. From 99 to $279 \mathrm{~m}$ in depth.

\section{Symbols used in the text}

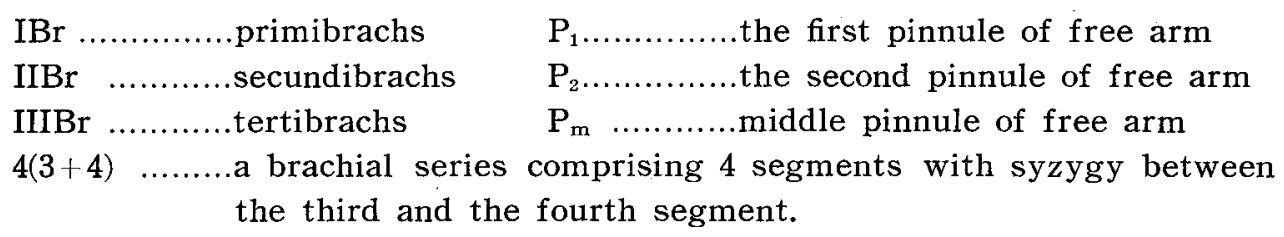

\section{REFERENCES}

Carpenter, P. H. 1888. The Comatulae. Challenger Reports, Zoology, vol. 26, pt. 60.

* Clark, A. H. 1907. Proc. U. S. Nat. Mus., vol. 33.

* 1908a. Proc. U. S. Nat. Mus., vol. 34.

* 1908b. Two new crinoid genera. Proc. Biol. Soc. Washington, 21.

* _ 1908c. Preliminary notice of a collection of crinoids from the Philippine

Islands. Smithsonian Misc. Coll. Washington, vol. 52, pp. 199-234.

* 1908d. Bull. Mus. Comp. Zool., vol. 51.

* - 1912a. Ann. Mag. Nat. Hist., ser. 8, vol. 10.

* _ _ 1 1912b. Notes Leyden Mus., vol. 34.

* 1915a. Journ. Washington Acad. Sci., vol. 5, no. 6.

1915b. A monograph of the existing crinoids. vol. 1, pt. 1, Bull. U. S. Natl.

Mus. 82, 406 pp., 513 text-figs., 57 pls.

1918. Unstalked crinoids of the Siboga Expedition. Siboga-Expeditie, monogr.

42b, 300 pp., 17 text-figs., 28 pls. Leyden.

- 1921. A monograph of the existing crinoids. vol. 1, pt. 2, Bull. U. S. Natl. Mus. 82. Washington. 795 pp., 949 text-figs., 57 pls.

1931. A monograph of the existing crinoids. vol. 1, pt. 3, Bull. U. S. Natl.

Mus. 82. Washington. 694 pp., 82 pls.

1941, '47, '50. A monograph of the existing crinoids. vol. 1, pts. 4a, b, c. Bull.

U. S. Nat. Mus. 82 . Washington. 603 pp., 61 pls.; 473 pp., 43 pls.; 383 pp., 32 pls.

CLARK, H. L. 1921. Echinoderm fauna of Torres Strait. Carnegie Inst. Washington. Papers Dept. Marine Biol., vol. 8, pp. 97-125.

DAN, K. and J. C. DAN 1941. Spawning habit of the crinoid, Comanthus japonicus. Jap. Jour. Zool., Tokyo, vol. 9, no. 4, pp. 555-564, 3 text-figs., pl. 14.

GISLÉN, T. 1922. Crinoids from Dr. S. Bock's expedition to Japan 1914. Nova Acta Reg. Soc. Sci. Upsal., ser. 4, vol. 5, no. 6, 184 pp., 162 text-figs., 2 pls.

1927. Papers from Dr. Th. Mortensen's Pacific Expedition 1914-16. 37. Japanese crinoids. Vidensk. Meddel. Dansk Naturhist. Foren., vol. 83.69 pp., 79 text-figs., 2 pls.

Hara, J. 1895. Description of a new species of Comatula. Antedon macrodiscus, n. sp. Zool. Mag., Tokyo, vol. 7, no. 81, pp. 115-116.

1896. On an unstalked crinoid Eudiocrinus japonius from Misaki (in Japanese)

Zool. Mag., vol. 8, no. 91, pp. 160-163.

HARA, J. and Y. OKadA 1921. Two new species of Myzostoma. Annot. Zool. Jap., vol. 10, art. 4 , pp. 33-39.

* Hartlaub, C. 1890. Nachr. Ges. Göttingen. 
Minobe, H. 1930. Descriptions of three comatulids (in Japanese). Zool. Mag., vol. 42, no. 497, pp. 110-119, 7 text.figs.

* Múller, J. $1841 . \quad$ Monatsb. preuss. Akad. Wiss.

UTINOMI, H. 1964. Coloured illustrations of seashore animals of Japan. Revised 8th printing (in Japanese). Hoikusha, Osaka. [Comatulida: pp. 105-106, pl. 53.]

1965. Crinoidea. In : New Illustrated Encyclopedia of the Fauna of Japan (in Japanese), pp. 10-20, figs. 1-38. Hokuryu-kan, Tokyo.

(* not referred to directly)

\section{EXPLANATION OF PLATE XII}

Fig. 1. Comanthina schlegeli (CARPENTER).

Fig. 2. Comanthus (Cenolia) japonica (MüLler).

Fig. 3. Comanthus (Comanthus) parvicirra (MülleR). Colour variants.

Fig. 4. Lamprometra parmata parmata (MüLLER). 
Publ. Seto Mar. Biol. Lab., XIII (4), 1965.

PLATE XII

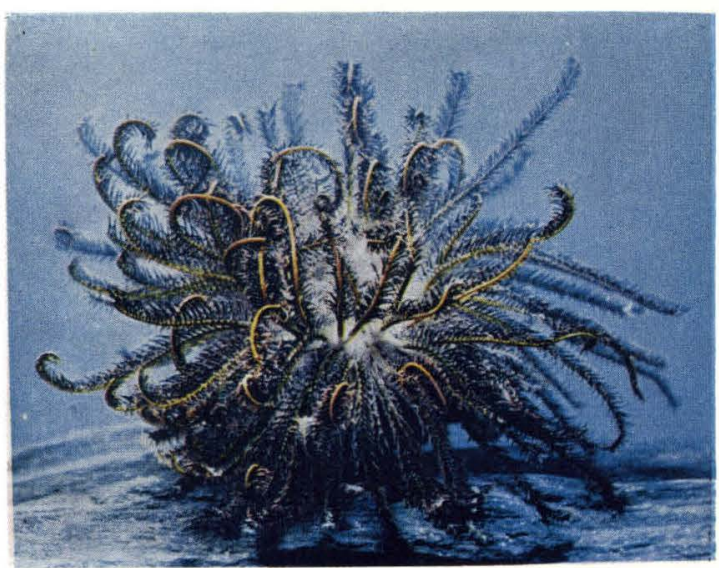

1

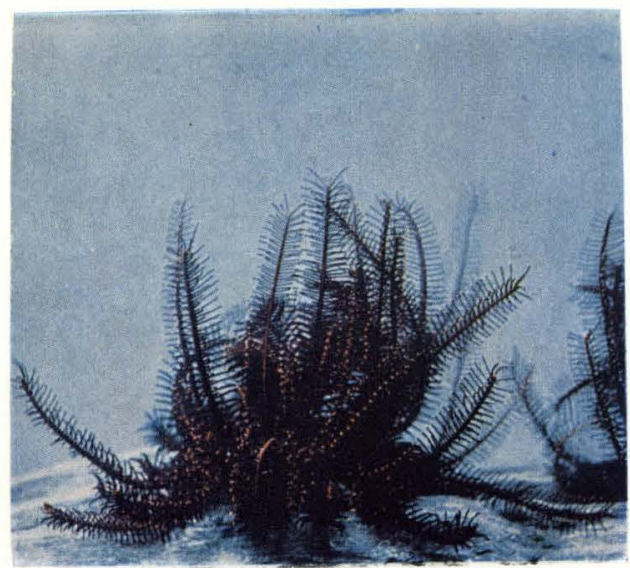

2

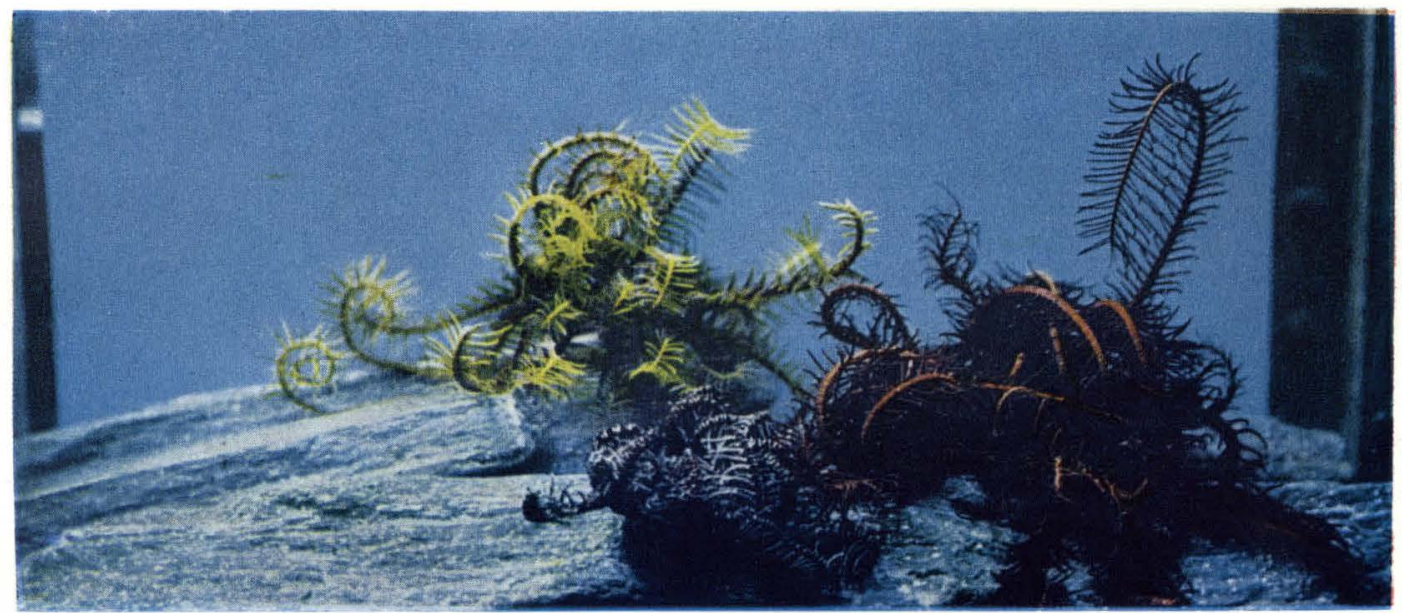

3

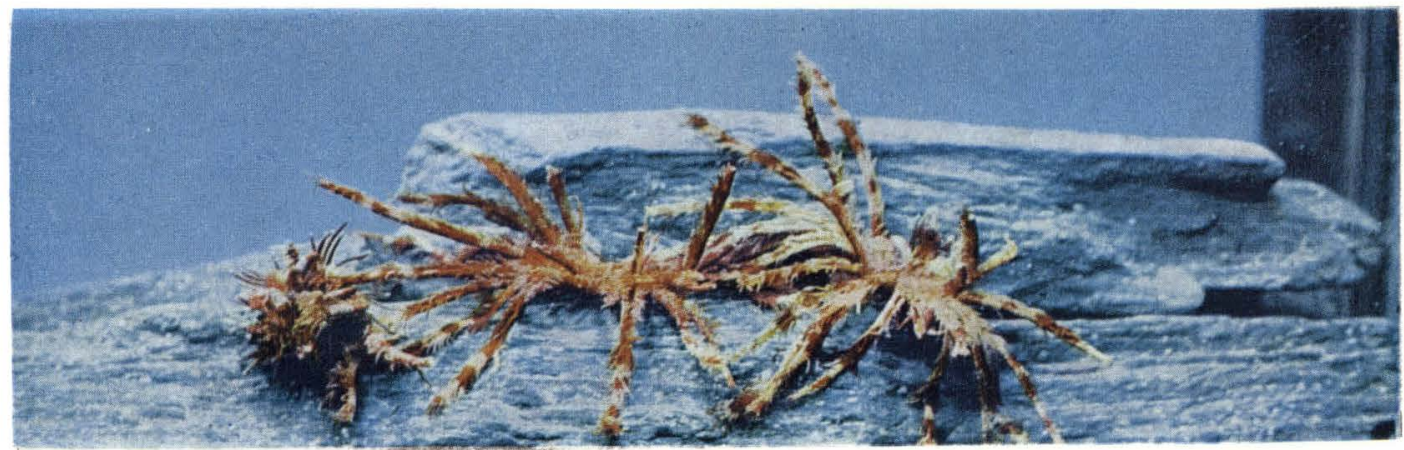

4

H. Utinomi and I. Kogo: Some Comatulids from Kii Coastal Sea. 